\title{
ABOUT THE STATUS OF THE DIALECTAL WORD
}

\section{Enazarov T.}

Doctor Of Philological Sciences, Associate Professor Of Uzbek Linguistics, Tashkent State University Of Uzbek Language And Literature Named After Alisher Navoi, Uzbekistan

\section{ABSTRACT}

This article focuses on the status of dialectal words, which is one of the most controversial issues in dialectology, in particular in "Uzbek dialectology". This issue proves that the status of a dialectal word is in practice only if it is expressed in the interpretation, description, interpretation, etymology, dialectal text, dialectal dictionary article and dialectal dictionaries of dialect words. The author has tried to cover this issue on the basis of a number of scientific and practical sources.

KEYWORDS: - Dialectal word, dialectal word status, dialectal word interpretation, dialectal word description, dialectal word explanation, dialectal word etymology, dialectal text, dialectal dictionary article and dialectal dictionaries and soon.

\section{INTRODUCTION}

When talking about the status of a dialectal word, the following should be taken into account: dialect-specific words, phrases and expressions are used very little or not used at all in literary language. Textbooks and manuals such as "the Uzbek language", "the Modern Uzbek literary language", "Lexicology of the Uzbek language" do not discuss dialectal words and dialectal meanings. At one point, the phrase of "a dialectal word" appeared [1, 247].

The term Dialect is a dialectal word with a second term to avoid duplication due to methodological features. Their forms of use in works of art are dialectisms [2, 203-211]. Therefore, 0. Madrahimov's opinion that "the question of the relation of the lexicon of living dialects to the lexical layers of the literary language is natural to attract the attention of researchers" $[3,80$.$] is also noteworthy. In the$ monograph "Vocabulary of the Oghuz dialect of the Uzbek language" the author notes that the dictionary he compiled is not a pure dialectal dictionary due to the comparative study of the words of the Oghuz dialect with the Turkic languages [4, 83-123.].

I would like to point out that the term dialectal word status was used in 2020 in a monograph entitled "Methodology of Dialectology" based on several years of practical dialectical observations [5,24-27-]. The status of a dialectal word differs in dialect words by its lexical-semantic and semantic (dialectal meaning) features, its noncompliance with the norms and requirements of literary language by its orthoepic and orthographic norms in relation to words in literary language, it differs from lexical units in literary language that it is rarely used or not used 
CURRENT RESEARCH JOURNAL OF PHILOLOGICAL SCIENCES 2(10): 41-

48, October 2021

DOI: https://doi.org/10.37547/philological-crjps-02-10-09

ISSN 2767-3758

(C)2021 Master Journals

Crossref doi) 81 Google

Accepted $26^{\text {th }}$ October, 2021 \& Published $31^{\text {th }}$ October, 2021

at all, and the lexical meaning they contain is a dialectal meaning that is rare in the system of meanings. This idea can also be seen in the analysis of examples. Of course, in this case, we will compare the dictionary articles of dialectal words given in "Dictionary of Uzbek folk dialects" with the dictionary articles of dialectal words prepared by us [6, see:]:

ABCAH (Jush) // ABCAP [Izoh] (Kashkadarya) foolish "недогадливый, несобразательный (1971, 12.12-) [[7, See:]]. Just as for some reason the dictionary does not provide a transcription of the dialectal word, it is arguable that the dialectal meaning it represents is given in Russian, as it is one of the dialectal words that has not yet been activated. Their transcriptional status was as follows: [авсан // avsan] // [авсар // avsar]. This dialectal word means "ignorant, careless" in Shakhrisabz dialect (informant ...). Therefore, it is one of the purest dialectal words.

АБЗАЛ I (Khorezm) - preferred (good, excellent) “лучший, преимущественый". (1971, 12.4-). Persian-Tajik word 'afzal' ( $\mathrm{f}>\mathrm{b}$ ) is a form of a word used in a dialect with a phonetic change. It is also arguable that the dictionary did not transcribe the dialectal word for some reason, nor did it translate the dialectal meaning it represents into Russian, as it is one of the dialectal words that has not yet been activated. Their transcriptional status was as follows: [абзал // abzal]. At the same time, the dialectal meanings of the word are clear: good, excellent, nice, right. (informant ...). It is one of the dialectal words formed from the borrowed word (i.e 'borrowing').

АБЗАЛ II (Khorezm) - harness “сбруя, упряжь” (1971, 12.5-). The dictionary article does not provide a transcription of the dialectal word, nor is the Russian translation of the dialectal meaning it represents controversial, as it is one of the less active dialectal words. Their transcriptional status was as follows: [абзал // abzal]. The word is a form of the Persian-Tajik preferred word $(\mathrm{f}>\mathrm{b})$ used in the dialect with a phonetic change. The meaning of this word is real: the horse's bridle, the horse's saddle. One of the dialectal words formed from the learned word.

From this it is clear that the additions we have made to the interpretations of dialectal words are in some sense justified. Of course, the role of dialectal texts in the speech of dialects is invaluable in substantiating this opinion and the examples given. Because the meaning and semantic relations of any word, especially dialect, are realized in the example of speech in the process of interaction. For example, the word 'kal' (trans. bold, hairless) is used in the literary language to refer to a person who has lost his hair, while in dialect it refers to a field where nothing grows $[8$, see]: “Шу жерләрдә эллънән бърэр гъйэх унмәйдъ, хэзъйәм. Шу учун унъ кәл дәлә дейъшәдъ". - No grass grows in these places, so it is called a bold field. But in the literary language the phrase 'kal dala' (trans. bold field) is not used at all. Because it is used in dialectal speech, the fact that the land without grasses is named in a way that has no relation to dialectal meanings is also due to the coordination of dialectical semantics and dialectal syntax. Thus, the first means of clarifying the dialectal status of the word sheva is dialectal texts and their scientific lexical analysis.

Another example, g'ilvindi which is a dialectual word (Shahrisabz, Saksonkapa), which is a type of Uzbek meat pie called 'somsa'. When used in a sentence, it gives it a dialectal meaning $[9$, see]:

[“Энәм бечррә, эттә туръп, хәмър қЭръп, сут пъшъръп, шърън вә гошлъ масаллықла бълә ғылвъндънъ ъккъ турънъ уЈққа тәшләп, пъшъръп эптъ. Јтәм эсә тушдә пәлэвдән элдънрэқ нәёб эвқәт богән ячмиччъ ъссъқ нән 
CURRENT RESEARCH JOURNAL OF PHILOLOGICAL SCIENCES 2(10): 41-

48, October 2021

DOI: https://doi.org/10.37547/philological-crjps-02-10-09

ISSN 2767-3758

(C)2021 Master Journals

Crossief do) 8 " Google

Accepted $26^{\text {th }}$ October, 2021 \& Published $31^{\text {th }}$ October, 2021

ва сәрёғдән тайууЈёрләп бедълә".

- My poor mother got up early, kneaded dough, boiled milk, and tossed and baked two kinds of gilvindi with delicious and meaty ingredients. In the afternoon, my father made hot bread and butter, a unique dish before palov.] [Note] It is clear from this dialectal text that the words g'ilvindi and yachmich had a dialectal meaning because they were used in the speech of one of the dialects and understood by other dialects. Thus, dialectal word is not formed by itself, but because it is used in conjunction with dialectal texts and its lexical units, it has a dialectal meaning that can be understood only by one (or several) dialect representatives. It is only after these processes that it becomes a dialectal word. From this it is clear that the status of a dialectal word is, in part, its position and importance among other words.

When speaking about the dialect's lexicon, the dialectal word, dialectism, and the diversity of dialectal features are given special emphasis in accordance with their time. But there is no comment on the term and concept of dialectal meanings in the dialectal lexicon of the dialect. In our opinion, the lexical units of the dialect have, of course, a dialectical meaning. It is natural, therefore, that they differ to some extent from the lexicon of literary language, just as they differ from dialect and dialect.

Such words exist in two different ways, such as the branching of the field of dialectology: 1) historical dialectal words (historical dialectology or materials on the history of language); 2) dialectal words (descriptive dialectology or modern dialectological materials) that are actively used in the speech of dialects today. Their grouping in this way reflects both the ancient existence of the Uzbek people and dialects, as well as the historical development of dialects.
There are two aspects to dialectal status:

1) practical aspect of dialectal word status;

2) Theoretical aspects of dialectal word status. At this point, before talking about its theoretical aspect, it is appropriate to talk about its practical aspect.

Materials of historical dialectology are found in stone inscriptions, historical and written literature, as well as in various folklore works such as folk epics in the form of special texts. It should also be noted that only during the Soviet period, due to the publication of some written sources, more dialectal words were compulsorily corrected with other words. The basis for this reasoning is the forced mispronunciation of the dialect words found in the reprint of the epic Alpomish. The contribution of the well-known dialectologist, Professor Khudoyberdi Doniyorov, to the positive conclusion of this issue, as well as to the fact that this epic is a folk epic in itself, is beyond price. During the period of independence, many of the dialectal words that express the essence of this epic were restored and republished. So, without the materials and texts of folklore, it is impossible to talk about the status of dialectal words.

In fact, Uzbek dialectal lexicography began with Mahmud Kashgari's "Devonu lugat-it turk" with Arabic explanations of the words of about twenty Turkic languages, but in the twentieth century it was replaced by dialectal words. and the interpretation of words was done under the influence of Soviet ideology, so that both the use and application of dialectal words were considered nationalistic in this period. Due to the same situation, Ahmad Ishaev, a senior researcher and candidate of philological sciences, was fired out in the early 1970s on charges of nationalism for stating in one of his articles that the gentle wind that blows when a door or window is opened can be called a 'yelvizak' 
CURRENT RESEARCH JOURNAL OF PHILOLOGICAL SCIENCES 2(10): 41-

48, October 2021

DOI: https://doi.org/10.37547/philological-crjps-02-10-09

ISSN 2767-3758

(C)2021 Master Journals

Crossief do) 8 " Google

Accepted $26^{\text {th }}$ October, 2021 \& Published $31^{\text {th }}$ October, 2021

(trans. breeze). This scientist himself told us that he had been fired out.

Dictionaries created in the tenth and nineteenth centuries, especially until the 1950 s of twentieth century, or more precisely, dialectal dictionaries, were to some extent sealed with a large number of dialect words. For example, in the dictionaries compiled by both creative and lexicographers, such as Abdulla Kodiri, a large number of dialect words have been studied [10,19-21]. Thus, the issue of a dialectal word and dialectal meaning was partially put into practice until the end of the 19 th century. That is why Alibek Rustamov called such a meaning "el ma'no" (i.e, meaning related to a dialect) $[11,94-]$. So, since dialectal words have a dialectal meaning, it is appropriate to talk about the status of a dialectal word.

Due to the socio-political situation, i.e at the request of the Soviet government, it was not possible to talk about dialectal words until the 20 s and 50s of the XX century. It was not until the second half of the 1950s that the issue of dialectal words began to receive practical attention. As a result, large and small scientific articles of young dialectologists, compiling dialects, began to be published one after another in scientific collections, which were recognized by the ideology of the time and their status at the level of scientific journals of that time. Many articles published in these scientific collections, along with materials on the phonetics and morphology of the dialect under study, are given based on the interpretation, description and scientific analysis of dialectal words related to the dialect, as if the phonetics, vocabulary and the fact that he was able to compile the material of its morphology in a large-scale article that would be a scientific book is also one of the proofs that clarifies the question of the status of dialectal words.

At that time, the main problems of dialectal word status were "What is the dictionary of dialect?", "How is the dialectal dictionary formed?" Wellknown scientists such as F. Abdullaev, M. Mirzaev, A. Gulyamov and A. Ishaev have published articles with recommendations and comments [12,36-41; 114-126,14,37-42, 4 -42]. In the essence of the same articles, the ideas of dialect, dialectal word, dialectal word types, dialectal dictionary article and dialectal dictionary, which are partly theoretical and more practical, are the first to be considered on the subject, given in the form of abstracts. In 1971, this process was intensified by the short and concise publication of the Dictionary of Uzbek Folk Dialects ("O'zbek xalq shevalari lug'ati"). The dictionary is based on the fact that dialectal words are not the same, 1) that is, to identify such words, to distinguish them from other words, and to dwell on their dialectal meanings; 2) on the basis of summarizing, grouping such words and dividing them into certain word types, it was necessary to make a rule, a theoretical generalization peculiar to dialectal words. To think about it, it was necessary to collect the entire dialectal lexicon of the Uzbek dialects, but this has not yet happened.

Since then, the published dialectal dictionaries have been individualized by the fact that they belong to the dialects of some sphere, village, town, city and region, despite their lexical and lexicographical shortcomings $[13,122 ; 466 ; 22$; 196; 222].

However, in "O'zbek xalq shevalari lug'ati" (the Dictionary of Uzbek Folk Dialects), published in 1971, it is necessary to focus on the types of dialectal words and their status, as well as on the beginning of words in dictionaries and terms and concepts related to the dictionary. The author who stopped briefly on their status was Ahmad Ishaev.

In the late 80 s of the XX century, more precisely, 
CURRENT RESEARCH JOURNAL OF PHILOLOGICAL SCIENCES 2(10): 41-

48, October 2021

DOI: https://doi.org/10.37547/philological-crjps-02-10-09

ISSN 2767-3758

(C)2021 Master Journals

Crossref do

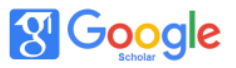

Accepted $26^{\text {th }}$ October, 2021 \& Published $31^{\text {th }}$ October, 2021

in 1988 the article "Shevalar lug'atiga kiritiladigan so'zlar" (Words to be included in the dictionary of dialects) and in 1989 the monograph "O'zbek dialektal leksikografiyasi" (Uzbek dialectal lexicography) was prepared and published by senior researcher Ahmad Ishaev. $[14,37-42-; 140$ p.]. In them, as we expect, on the question "What is a dialectal word, more precisely, the status of a dialectal word and a dialectal dictionary?" the author discusses a number of achievements in the field of Uzbek dialectology in the second half of the twentieth century. For this reason, the author was the first in the field of Uzbek linguistics to express his views on the status of dialectal words and types of dialectal words based on a number of scientific achievements in Uzbek linguistics, based on dialectal materials of the Turkic languages. The author tried to bring his ideas about dialectal words, dialectal lexicon, dialectal lexicography to the norm in this monograph.

Speaking about the status of dialectal words, Mahmud Kashgari said that the figurative meanings of such words are in the example of the words yo'go'ro'g, yitldi'zlan, tal, qachach, the etymology of some of them is obscure, although an attempt has been made to clarify with the examples of the words to'msa, chaxshi, xasnit, tovill [15, 26-27, 27-28.], these issues related to these words have also been forgotten these days.

The theoretical aspect of dialectal word status is the development of its own norms and principles (laws). Let's take a look at how this issue is expressed in prepared and published dialectal dictionaries. Let's take a look at the meaning of Mahmud Kashgari's "Devonu lugat-it turk". The work is based on several years of dialectological observations in accordance with the requirements of Arabic lexicography. Just as there was no mention of literary language at that time, the author does not speak in detail about the types and meanings of dialectal words, but also paid a serious attention to lexical articles based on lexical and lexicographic studies of Turkic words based on the requirements of Arabic lexicography [16, see].

The most recorded examples of the epic "Alpomish" are in the Karakalpak and Uzbek languages. Eight versions of the epic in the Karakalpak language and the Uzbek version have been recorded thirty-five times in full, in the form of fragments and descriptions of more than thirty folk epics" [17,5-]. However, in the explanatory dictionary of the epic "Alpomish" compiled under the leadership of the well-known folklorist, academician Tora Mirzaev, there is also an inappropriate, incorrect change and inappropriate correction of the Kipchak dialect and dialect words. The interpretation of settings $[18,5-87]$ is an example of this.

The reason for the focus on the issue of dialectal word status is that the dictionary articles in this dictionary are the basis, and I would be more reasonable. This is because the dictionary articles on the lexicon of the Turkic languages in this work were the impetus for our ideas about the status of dialectal words, just as we read, read and studied the dictionary articles in it. It should be noted that the dictionary articles in this work differ from the dictionary articles in dialectal dictionaries created in later periods in terms of content and volume.

If we look at the dictionaries of the later period in terms of dialectal word status, it was observed that the dictionary articles in them go beyond two or three lines, and in some words only up to 7-8 lines (that is examples from dialectal dictionary articles are given above). This can be attributed to the lack of relevant materials, the misuse of existing materials, and, ultimately, the lack of dialectal lexicographic norms and requirements. Speaking about the status of dialectal words, it is necessary to note the 
CURRENT RESEARCH JOURNAL OF PHILOLOGICAL SCIENCES 2(10): 41-

48, October 2021

DOI: https://doi.org/10.37547/philological-crjps-02-10-09

ISSN 2767-3758

(C)2021 Master Journals

Crossref do

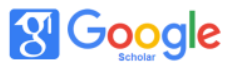

Accepted $26^{\text {th }}$ October, 2021 \& Published $31^{\text {th }}$ October, 2021

following axiom: it is natural that dictionaries dedicated to the lexicon of literary language, their internal structure and the expression of dictionary articles are radically different from dialectal dictionaries and dialectal dictionary articles...

However, this situation has not been studied theoretically yet. This shows researchers the lexicographical interpretation and analysis of dialectal word status. And again, paying attention to the fact that the term the Uzbek literary language' has been used since the second half of the XX century, until the 50s of the XX century it's clear that there were no concepts and terms of the old Uzbek literary language and the modern Uzbek literary language. Also, the term of the old Uzbek literary language was introduced into the tradition in the 40s and 60s of the XX century, as a novelty and conditionally new term in the field of science through the efforts of academicians V. Abdullaev and Professor N. Mallaev. However (Kokand (Fergana), Samarkand, Tashkent, Khiva, Bukhara) it is correct to give the concept of literary environment (s) in terms of the old Uzbek literary language from the point of view of literary art, but to the dialects themselves. But in terms of the specific position of the dialects (Kokand (Fergana), Samarkand, Tashkent, Khiva, Bukhara) to increase the importance of the literary environment, each of which has its own linguistic features, with the term and concept of the old Uzbek literary language is incorrect in a certain sense. From the above analysis, it can be concluded that we are right to call the dictionaries created before 1956, in a sense, dialectical lexicographic studies, even if it is a bitter truth.

If we consider the fact that the manuscripts and stone-printed materials on the history of language from the IX-X centuries to the end of the XIX century belong to the historical dialectology, it is natural that they remain the main scientific and practical sources of historical dialectology.

The growing need to replace a number of borrowed words with Uzbeks during the period of independence also highlights the importance of dialectal status. For example, the borrowed words chiqindi and musir are inappropriate to use from the point of today's cultural development because they have a very negative meaning in our language. They should be replaced by the word quqim, which is used in the Kipchak dialect, especially in Samarkand, Kashkadarya and Surkhandarya regions. It is a general Turkic and Uzbek word that expresses palatal synharmonism. This word can be used in a more positive sense than the words chiqindi and musir.

The word can be used in a more positive sense than the words chiqindi or musir. Because we Uzbeks have a separate layer of bread crumbs and food scraps around the table, a separate layer of small things that come out when sweeping the house, a separate layer of dishwashing detergent, a piece of garbage left on the street and excess items in the toilet are also a separate garbage. These are the onomasiological possibilities of the word quqim.

Ushbu so'z chiqindi yoki musir so'zlariga nisbatan ancha ijobiy ma'noda qo'llash mumkin. Chunki biz o'zbeklarda dasturxon atrofida tushgan non ushoqlari, ovqat qoldiqlari alohida quqim bo'lsa, uyni supirish-siyirishda chiqqan mayda chuyda narsalar ham alohida quqim, qozon-tovoqni yuvishdagi yuvindi-chayindilar ham alohida quqim, ko'cha-kuydagi tashlandiq narsa va hojatxonadagi ortiqcha narsalar ham alohida quqim hisoblanadi. Bular quqim so'zining onomasiologik imkoniyati.

If you pay attention, right now QUQIMXONA ( - a very positive word) (i.e MUSIRXONA ( - consider it has a negative meaning) there are several 
CURRENT RESEARCH JOURNAL OF PHILOLOGICAL SCIENCES 2(10): 41-

48, October 2021

DOI: https://doi.org/10.37547/philological-crjps-02-10-09

ISSN 2767-3758

(C)2021 Master Journals

Crossref do

81 Google

Accepted $26^{\text {th }}$ October, 2021 \& Published $31^{\text {th }}$ October, 2021

small separate QUQIMXONA for food scraps, bread and bread crumbs, for household waste, and for coarse items. These are the natural and social factors in the use of the word 'quqim'. So, it would not be a mistake to use the word 'quqim' instead of the word 'musir' and the word 'quqimhona' instead of the word 'musirxona'. Because the philosophy of our people in the use of words is perfect, delicate in taste, strong in attention - can quickly distinguish positive from negative.

So, it is necessary to pay attention to the following theoretical aspects of the status of dialectal words:

1) their use in different meanings and forms by representatives of dialects and dialects;

2) they have lexical meaning in the form of dialectal meanings.

Of course, the following are practical aspects of dialectal word status:

1) recording of speeches of dialects as texts;

2) their presentation in dictionaries of different periods;

3) their inclusion from a simple dialectal dictionary to a perfect dialectal dictionary;

4) the general description and analysis of dialectal words in such dictionaries;

5) activation of lexical meanings as a result of strengthening of lexical traditions and obscurity of dialectal meaning;

6) the spiritual need for the creation of perfect dictionaries as a result of the transition of dictionary articles from the need to the evidence-rich analytical situations. However, neither of these two cases has reached the level of perfection in terms of the complete coverage of dialectal information in dialect materials, nor in terms of methods and techniques used in the use of materials of existing dialects.

From this it can be concluded that it is scientific research of the status of dialectal words is the right of dialect words, among other words, the possibility of their use and application; interpretation, description, interpretation and etymology; its unique position in the strategy of semantic relations with dialectal meanings in relation to other similar words, as well as in literary language, and in accordance with the dialectical lexicon and dialectal lexicographic requirements in terms of practical as well as theoretical aspects underlying this position.

\section{REFERENCES}

1. Ўзбек тили лексикологияси. -Тошкент: Фан, 1981. -В. 247.

2. 2.Файзуллаев Б. Бадиий адабиётда диалектизмларнинг стилистик вазифалари // Тилшунослик масалалари. -Тошкент: Фан, 1978. -В.203-211.

3. Мадрахимов О. Ўзбек тилининг ўғуз лахжаси лексикаси. -Тошкент: Фан, 1973. -B. 80.

4. Мадрахимов О. Ўзбек тилининг ўғуз лахжаси лексикаси. -Тошкент: Фан, 1973. -B. 83-123.

5. Enazarov T. Dialektologiya metodologiyasi (monografiya). -Toshkent: Innovasiya-Ziyo, 2020. -B. 24-27.

6. Misollardagi (1971, 12.12-) gacha bo'lgan fikrlar shu so'zga 1971-yilda nashr etilgan “Ўзбек халқ шевалари луғати"da berilgan. Qoraytirilgan qismi esa shu so'z talqiniga biz tomondan qo'shilgan fikrlar. 
CURRENT RESEARCH JOURNAL OF PHILOLOGICAL SCIENCES 2(10): 41-

48, October 2021

DOI: https://doi.org/10.37547/philological-crjps-02-10-09

ISSN 2767-3758

(C2021 Master Journals

Crossref doi) 81 Google

Accepted26 ${ }^{\text {th }}$ October, 2021 \& Published $31^{\text {th }}$ October, 2021

7. Quyida namuna uchun berilayotgan lug'at maqolalarning yozuv shakli o'zgarsa, matn boshqa holatga kelib qolishining oldini olish uchun tayyorlanayotgan dialektal lug'atda ular qanday berilgan bo'lsa, shu tarzda o'zgarishsiz qayd etildi.

8. Qavsda berilgan (1971, 12.12-) dan keyin keltirilgan fikrlar uchala lug'at maqolaga biz qo'shgan qo'shimchamizdir.

9. $\mathrm{Bu}$ matn sheva vakillarining suhbatidan yozib olingan.

10. Нормаматов С. Э. Ўзбек луғатчилигининг шаклланиши ва ривожланишида жадид маърифатпарварларининг ўрни. 10.00.01 - Ўзбек тили. Филология фанлари доктори (DSc) диссертацияси автореферати. -Тошкент, 2019. -В. 19-21.

11. Рустамов А. Сўз хусусида сўз. - Тошкент: EXTREMUM PRESS, 2020. -B.94.

12. Абдуллаев Ф. А. Диалектал луғат тузиш принциплари // ЎТА.

Тошкент, 1966. 2-сони.-В.35-41. Мирзаев М. Диалектал сўзлар // Ўзбек шевалари лексикаси. -Тошкент, 1966. -В.114-326. Ғуломов А. Ғ. Диалектал луғат хақида // Ўзбек тили ва адабиёти. 1968. 4-сони. B.14. Ишаев А.Шевалар луғатига киритиладиган сўзлар // Ўзбек тили ва адабиёти. 1988. 2-сони. -В.37-42. Ишаев А. Ўзбек диалектал лексикографияси. Тошкент: Фан, 1990. -Б. 4-42.

13. Рахимов С. Сурхондарё ўзбек шевалари луғати.-Денов,1993. 122 бет. Нафасов Т. Қашқадарё ўзбек халқ сўзлари. -Тошкент: Мухаррир, 2011. 466 бет. Садиков Т.Лексика говоров Ташкентской области. АКД. -Ташкент, 1968.c. 22. Туйчибоев Б., Ширинов С., Қашқирли Қ. Туганмас бойликлар булоғи. -Тошкент, Ўқитувчи, 1991.196 бет.Тўйчибоев Б.,
Қашқирли қ. Зомин сўзлиги. -Тошкент, 2008. 222 бет ва бошқалар.

14. Ишаев А. Шевалар луғатига киритиладиган сўзлар // Ўзбек тили ва адабиёти. 1988. 2-сони.37-42-бетлар. Ишаев А. Ўзбек диалектал лексикографияси. -Тошкент: Фан, 1990. 140 б.

15. . Дадабоев X. “Девону луғотит туркнинг тил хусусиятлари.-Тошкент, 2017. -Б.2627, 27-28.

16. Qarang: Махмуд Кошғарий. Девону луғотит турк. Уч томлик. I т.

Тошкент: Фан, 1960. II т.-Тошкент: Фан, 1961. III том. -Тошкент: Фан, 1963.

17. T. Mirazyev. Doston gultoji. "Alpomish" dostoniga yozilgan so'zboshi.

Toshkent: Sharq NMAK Bosh tahririyati, 2010. 5-bet.

18. Mirzayev T., Eshonqul J., Fidokor $S$. "Alpomish" dostoning izohli lug'ati. Toshkent: Fan, 2007. -B. 5-87. 